\title{
Kajian Kelimpahan Mikroplastik di Perairan Teluk Benoa Provinsi Bali
}

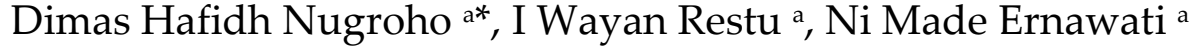 \\ a Program Studi Manajemen Sumberdaya Perairan, Fakultas Kelautan dan Perikanan, Universitas Udayana, Bukit Jimbaran, Bali-Indonesia \\ * Penulis koresponden. Tel.: +62-857-388-803-21 \\ Alamat e-mail: dimashafidh@gmail.com
}

Diterima (received) 25 Agustus 2018; disetujui (accepted)14 November 2018

\begin{abstract}
Benoa Bay is one of the water areas with quite complex activities, starting from Benoa harbor activities, watersports, tourism, fishing activities and others. The complexity of the use of Benoa Bay is thought to provide input on pollution of marine waste, one of which is plastic waste. The purpose of this study is to determine the type and abundance of microplastic found in the waters of Benoa Bay, Bali. This research was conducted from March to May 2018. Microplastic sampling in water using $200 \mu \mathrm{m}$ plankton net was withdrawn for 10 minutes. Taking microplastic samples in sediments using a shovel. The results showed that in the water and sediment in Benoa Bay, 3 types of microplastic were found, namely fragments, films and fibers. The highest microplastic type in the waters came from the type of fragment with an abundance of 0.26 particles $/ \mathrm{m}^{3}$ found at station 3 . The abundance of total microplastic in the highest waters was found at station 3 with an abundance of 0.58 particles $/ \mathrm{m}^{3}$. The highest microplastic type in the sediment comes from the type of fragment with an abundance of 57 particles / $\mathrm{kg}$ found at station 1 . The total abundance of microplastic in the highest sediment is found at station 1 with an abundance of 113 particles / $\mathrm{kg}$.
\end{abstract}

Keywords: Microplastics, Benoa Bay, Fragment, Film, Fiber.

\section{Abstrak}

Teluk Benoa merupakan salah satu daerah perairan dengan aktivitas yang cukup kompleks, mulai dari aktivitas pelabuhan benoa, wisata olahraga air (watersports), pariwisata, kegiatan perikanan dan lain-lain. Kompleksitas pemanfaatan Teluk Benoa diduga memberikan masukan pencemaran sampah laut salah satunya sampah plastik. Tujuan penelitian ini yaitu untuk mengetahui jenis dan kelimpahan mikroplastik yang terdapat di perairan Teluk Benoa, Bali. Penelitian ini dilakukan pada bulan Maret hingga Mei 2018. Pengambilan sampel mikroplastik di air menggunakan plankton net dengan ukuran $200 \mu \mathrm{m}$ yang ditarik selama 10 menit. Pengambilan sampel mikroplastik di sedimen menggunakan sekop. Hasil penelitian menunjukkan bahwa pada badan air dan sedimen di Teluk Benoa ditemukan 3 jenis mikroplastik yaitu fragmen, film, dan fiber. Jenis mikroplastik tertinggi di perairan berasal dari jenis fragmen dengan kelimpahan sebesar 0,26 partikel $/ \mathrm{m}^{3}$ yang ditemukan pada stasiun 3. Kelimpahan total mikroplastik di perairan tertinggi terdapat pada stasiun 3 dengan kelimpahan sebesar 0,58 partikel $/ \mathrm{m}^{3}$. Jenis mikroplastik tertinggi di sedimen berasal dari jenis fragmen dengan kelimpahan sebesar 57 partikel/kg yang ditemukan pada stasiun 1 . Kelimpahan total mikroplastik di sedimen tertinggi terdapat pada stasiun 1 dengan kelimpahan sebesar 113 partikel/kg.

Kata Kunci: Mikroplastik, Teluk Benoa, Fragmen, Film, Fiber.

\section{Pendahuluan}

Sampah laut (marine debris) adalah benda padat diproduksi atau diproses secara langsung atau tidak langsung, sengaja atau tidak sengaja, dibuang atau ditinggalkan di dalam lingkungan laut oleh manusia (NOAA, 2013). Menurut Hastuti
(2014), beberapa jenis sampah laut yang dapat ditemukan di antaranya plastik, kain, busa, gabus, kaca, keramik, logam, kertas, karet, dan kayu. Tipe plastik merupakan jenis sampah laut dominan di antara tipe sampah laut (CBD-STAP, 2012). Menurut Galgani (2015) dalam Victoria (2017), 95\% dari total sampah yang terakumulasi di sepanjang 
garis pantai, permukaan dan dasar laut adalah jenis sampah plastik.

Berbagai macam masalah muncul akibat adanya sampah laut (marine debris) seperti berkurangnya keindahan wilayah pesisir, minimbulkan berbagai macam penyakit, mempengaruhi jaring - jaring makanan, serta berkurangnya produktivitas ikan yang ditangkap. Bila hal tersebut terjadi, maka berpengaruh terhadap rantai makanan, perekonomian dan kesehatan masyarakat di daerah tersebut (Citrasari et al., 2012). Sampah plastik memiliki bahan berbahaya dan beracun dari sampah plastik akan mengakibatkan ikan dan biota laut lainnya mengalami gangguan bahkan pada konsentrasi yang tinggi sekali dapat mengakibatkan terjadinya kematian. Sampah plastik juga akan berdampak pada kehidupan manusia terutama kesehatan, bahaya racun bisa masuk ke dalam tubuh melalui air yang kita gunakan dan juga makanan hasil laut yang biasa kita konsumsi. Sampah plastik berpotensi untuk menurunkan, atau bahkan dapat menyebabkan hilangnya keanekaragaman hayati ekosistem pesisir (Aruna, 2017).

Salah satu limbah plastik yang dapat mempengaruhi siklus makanan di wilayah pesisir dan laut adalah mikroplastik. Mikroplastik merupakan partikel plastik yang diameternya berukuran kurang dari $5 \mathrm{~mm}$. Secara proses kimiawi, potensi dampak sampah laut akan cenderung meningkat seiring menurunnya ukuran partikel plastik (mikroplastik) (UNEP, 2011). Mikroplastik memiliki potensi menyebabkan terganggunya rantai makanan apabila menumpuk di wilayah perairan. Mikroplastik berpotensi memiliki potensi ancaman lebih serius dibanding dengan material plastik yang berukuran besar bagi organisme yang mendiami tingkatan tropik yang lebih rendah, seperti plankton yang mempunyai partikel rentan terhadap proses pencernaan mikroplastik sebagai akibatnya melalui proses bioakumulasi dapat mempengaruhi organisme tropik tingkat tinggi. Hasil uji laboratorium menunjukkan bahwa mikroplastik dapat dikonsumsi oleh organisme laut ketika mikroplastik memiliki bentuk menyerupai makanan (Boerger et al., 2010; Browne et al., 2008; Lusher et al., 2012; Van Cauwenberghe et al., 2013).

Terdapat 5 lokasi stasiun pengambilan sampel di Teluk Benoa, yaitu:
Salah satu wilayah di Provinsi Bali yang memiliki kerentanan pencemaran mikroplastik yaitu perairan Teluk Benoa. Teluk Benoa merupakan salah satu daerah perairan dengan aktivitas yang cukup kompleks, mulai dari aktivitas pelabuhan benoa, wisata olahraga air (watersports), maupun aktivitas dari pemukiman penduduk. Aktivitas tersebut diduga memberikan kontribusi pencemaran sampah laut yang terhadap teluk Benoa yang diperparah oleh dua sungai besar dari kawasan Kota Denpasar atau Kabupaten Badung yaitu Sungai Badung dan Sungai Mati yang bermuara di Teluk Benoa, ditambah beberapa sungai kecil. Dengan adanya pencemaran sampah laut di teluk Benoa dapat mengganggu berbagai aktivitas yang terjadi di Teluk Benoa. Namun, belum pernah ada penelitian tentang mikroplastik di Teluk Benoa sehingga belum dikatahui adanya kontaminasi mikroplastik di perairan Teluk Benoa yang dapat menjadi

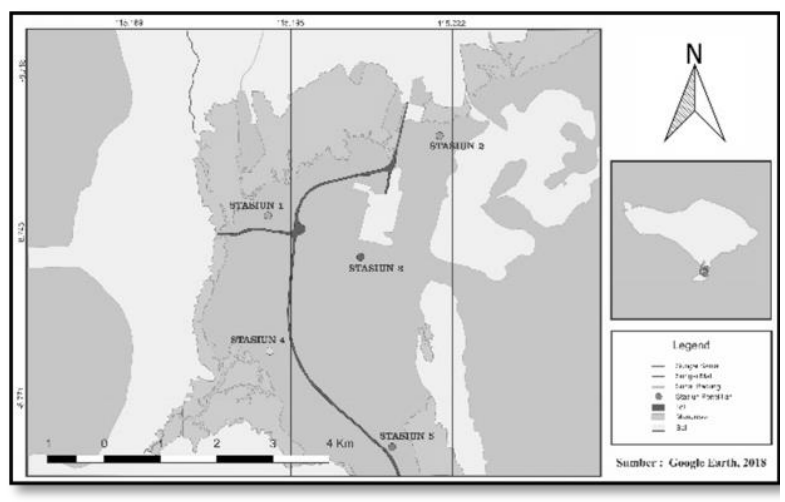

Gambar 1. Lokasi Penelitian

kendala dalam strategi pengelolaan Teluk Benoa dari pencemaran sampah. Oleh karena itu diperlukan penelitian tentang kajian kelimpahan mikroplastik di perairan Teluk Benoa.

\section{Metode Penelitian}

\subsection{Waktu dan Tempat}

Kegiatan penelitian telah dilaksanakan di perairan Teluk Benoa pada bulan Maret sampai dengan Mei 2018. Penentuan lokasi (stasiun) penelitian menggunakan metode purposive sampling. Setiap stasiun mewakili aktivitas yang terdapat perairan Teluk Benoa. Pada setiap stasiun diambil satu sampel menggunakan metode random sampling.

1. Stasiun 1 : Daerah dekat muara dari Sungai Badung dan Sungai Mati ( $8^{\circ} 44^{\prime} 36,61^{\prime \prime} S$; $115^{\circ}$ $11^{\prime} 12,13^{\prime \prime} \mathrm{E}$ ) 
2. Stasiun 2 : Daerah Pelabuhan dekat Tempat Pembuangan Akhir (TPA) Suwung. (8 43' 40,29" S ; 115'13' 10.39" E )

3. Stasiun 3 : Daerah tengah perairan Teluk Benoa. ( $8^{\circ} 44^{\prime}$ 52,83" S ; 115 12' 37,03” E )

4. Stasiun 4 : Daerah dekat muara dari Sungai

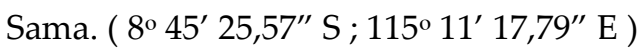

5. Stasiun 5 : Daerah dekat muara Sunga Bualu ( $8^{\circ} 46^{\prime} 23,38^{\prime \prime} \mathrm{S} ; 115^{\circ} 12^{\prime} 36,18^{\prime} \mathrm{E}$ )

\subsection{Alat dan Bahan}

Alat penelitian yang digunakan yaitu plankton net $200 \mu \mathrm{m}$, ember, botol, current meter, cool box, kamera (Xiaomi redmi note 2, China), alat tulis, mikroskop (Olympus CX2FS1, Filipina, optic lab, cawan petri, pinset, saringan $200 \mu \mathrm{m}$, gps (GPS Status \& Toolbox vers. 9.0.183), dan gelas ukur. Bahan yang digunakan yaitu aquades, larutan $\mathrm{KOH} 10 \%$, dan $\mathrm{NaCl}$.

\subsection{Metode Penelitian}

Metode yang digunakan pada penelitian ini adalah metode obsevasi. Pengambilan sampel dilakukan setiap 2 minggu sekali sebanyak 3 kali pada 5 stasiun. Pengambilan sampel air dilakukan saat perairan surut menuju pasang. Pengambilan sampel sedimen dilakukan saat perairan surut terendah. Sampel air dan sedimen dibawa ke Laboratorium Perikanan Fakultas Kelautan dan Perikanan Universitas Udayana (ex situ) untuk mengetahui jenis dan kelimpahan mikroplastik. 82

2.3.1 Pengambilan Sampel dan Identifikasi Jenis Mikroplastik Pada Perairan

Metode pengambilan sampel mikroplastik yang digunakan dimodifikasi dari Kovac (2016). Pengambilan sampel mikroplastik diawali dengan meletakan plankton net dengan ukuran $200 \mu \mathrm{m}$ di sisi kapal dengan jarak 1-2 m untuk menghindari turbulensi air yang disebabkan gesekan air dengan kapal. Koordinat GPS awal dan waktu awal dicatat pada lembar data saat kapal mulai bergerak dalam satu arah lurus dalam waktu 10 menit dengan kecepatan rata-rata 1 knot. Setelah 10 menit kapal dihentikan, kemudian dituliskan koordinat GPS akhir, panjang rute dan kecepatan kapal rata-rata ke lembar data yang disediakan dan angkat plankton net keluar dari air. Plankton net dibilas secara menyeluruh dari luar jaring dengan air menggunakan ember. Sampel air yang telah tersaring dipindahkan ke botol sampel. Botol dibersihkan dan diberi label diluar botol dengan nama sampel dan tanggal dengan spidol tahan air.

Identifikasi jenis mikroplastik dilakukan di Laboratorium Perikanan Fakultas Kelautan dan Perikanan Universitas Udayana. Sampel dituangkan ke gelas ukur lalu didiamkan selama 24 jam dengan kondisi gelas ukur tertutup alumunium foil. Mikroplastik yang memiliki densitas rendah akan mengapung di permukaan. Untuk sampel yang didalamnya terdapat alga, dilakukan inkubasi dengan larutan $\mathrm{KOH} 10 \%$ dengan suhu $60{ }^{\circ} \mathrm{C}$ selama 24 jam. Partikel mikroplastik yang mengapung diambil menggunakan pinset kemudian diletakkan di cawan petri. Amati dibawah mikroskop untuk mengidentifikasi jenis mikroplastik. Setelah mengeluarkan partikel mikroplastik yang mengapung, saring kembali partikel yang mengendap lalu diletakkan di cawan petri kemudian diamati dibawah mikroskop dengan perbesaran 4x dan 10x. Metode untuk identifikasi jenis mikroplastik yang digunakan mengacu dari Kovac (2016).

2.3.2 Pengambilan Sampel dan Identifikasi Jenis Mikroplastik Pada Sedimen

Pengambilan sampel sedimen dilakukan dengan

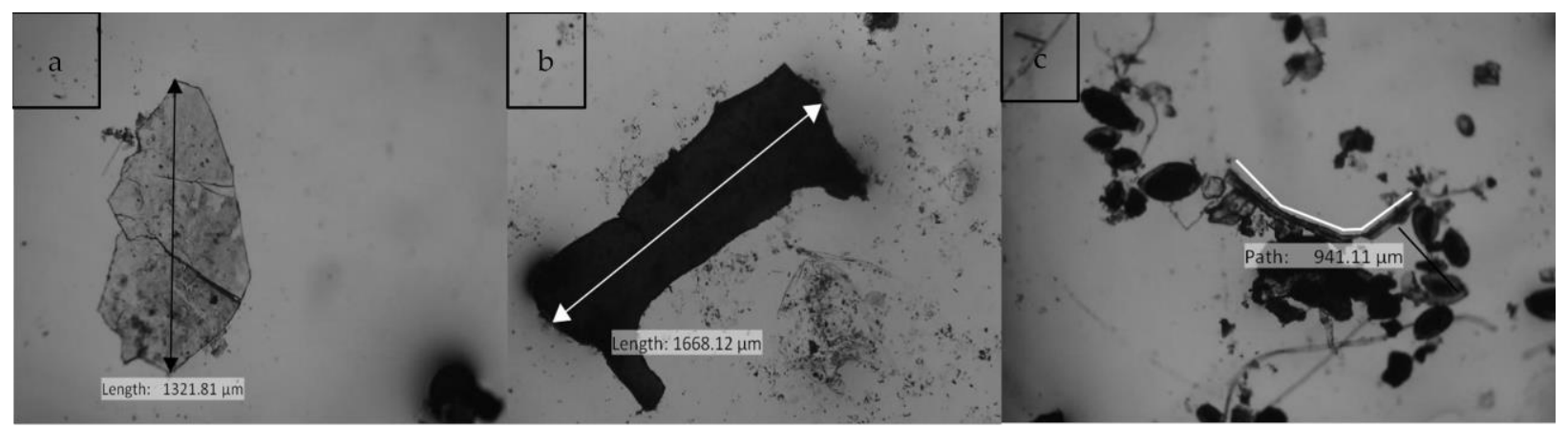

Gambar 2. Jenis Mikroplastik yang ditemukan di Perairan Teluk Benoa Fragmen (a), Film (b), dan Fiber (c) 
alat bantu sekop pada setiap stasiun. Tahap pertama yang dilakukan yaitu pengeringan dengan oven $60{ }^{\circ} \mathrm{C}$ selama 24 jam. (Hidalgo-Ruz et al., 2012). Tahap pemisahan densitas dilakukan dengan mencampurkan sampel sedimen kering (100 gram) dan larutan air Laut kemudian campuran diaduk selama 2 menit. Tahap penyaringan dilakukan dengan menyaring menggunakan saringan $200 \mu \mathrm{m}$. Partikel mikroplastik yang mengapung dipermukaan dipilah secara visual dibawah mikroskop dengan perbesaran $4 \times$ dan $10 \times$ lalu identifikasi jenis mikroplastik sesuai dengan Kovac (2016).

\subsection{Analisis Data}

\subsubsection{Kelimpahan mikroplastik di Air}

Kelimpahan mikroplastik dapat dihitung berdasarkan jumlah partikel yang ditemukan dibagi air yang tersaring (NOAA, 2013).

$C=\frac{n}{V}$

dimana $C$ adalah kelimpahan (partikel $/ m^{3}$ ); $n$ adalah jumlah partikel; dan $V$ adalah volume air tersaring $\left(\mathrm{m}^{3}\right)$.

Volume air tersaring dapat dihitung dari mengalikan dari luas mulut plankton net dengan jarak tarikan plankton net (Wardhana, 2003).

$V=L x S$

dimana $V$ adalah volume air tersaring $\left(\mathrm{m}^{3}\right) ; L$ adalah luas mulut plankton net; dan $S$ adalah jarak tempuh.
2.4.2. Kelimpahan mikroplastik di sedimen

$C=\frac{n}{m}$

dimana $C$ adalah kelimpahan (partikel/kg); $n$ adalah jumlah partikel; $m$ adalah berat sedimen kering $(\mathrm{kg})$

\section{Hasil dan Pembahasan}

\subsection{Mikroplastik di perairan Teluk Benoa}

Hasil penelitian menunjukkan bahwa dalam air yang diambil di perairan Teluk Benoa mengandung beberapa jenis mikroplastik. Jenis mikroplastik yang ditemukan yaitu fragmen, film, dan fiber. Partikel mikroplastik yang ditemukan di perairan Teluk Benoa memiliki ukuran $58 \mu \mathrm{m}-4$ $\mathrm{mm}$.

Berdasarkan hasil penelitian, rata-rata mikroplastik jenis fragmen yang ditemukan berkisar antara 8 - 11,7 partikel. Jenis fragmen tertinggi ditemukan pada stasiun 3 dengan jumlah 11,7 partikel dan terendah ditemukan pada stasiun 5 dengan jumlah 8 partikel. Rata-rata mikroplastik jenis film yang ditemukan berkisar antara 7,3 - 11 partikel. Jenis film tertinggi ditemukan pada stasiun 3 dengan jumlah 11 partikel dan terendah ditemukan pada stasiun 3 dan 5 dengan jumlah 7,3 partikel. Rata-rata mikroplastik jenis fiber yang ditemukan berkisar antara 2,3 - 4,7 partikel. Jenis fiber tertinggi ditemukan pada stasiun 2 dengan jumlah 4,7 partikel dan terendah ditemukan pada stasiun 4 dengan jumlah 2,3 partikel. Jumlah dan

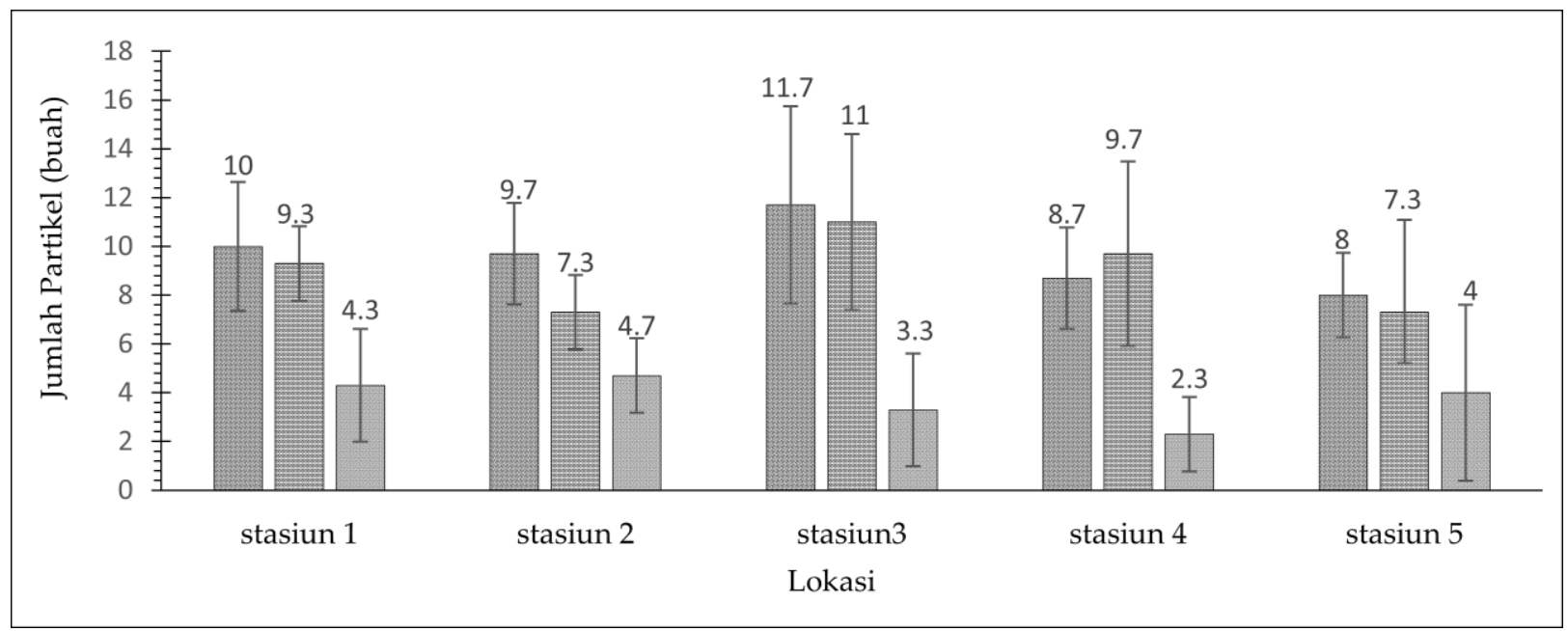

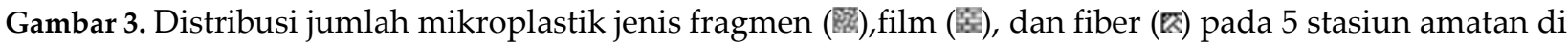
Perairan Teluk Benoa. 
jenis mikroplastik di masing-masing stasiun dapat dilihat pada Gambar 3.

Kelimpahan total mikroplastik di perairan Teluk Benoa berkisar dari 0,43-0,58 partikel $/ \mathrm{m}^{3}$. Kelimpahan tertinggi ditemukan pada stasiun 3 yaitu 0,58 partikel/ $\mathrm{m}^{3}$, sedangkan kelimpahan terendah ditemukan pada stasiun 5 yaitu 0,43 partikel/ $\mathrm{m}^{3}$. Kelimpahan total mikroplastik di masing-masing stasiun secara rinci dapat dilihat pada Gambar 4.

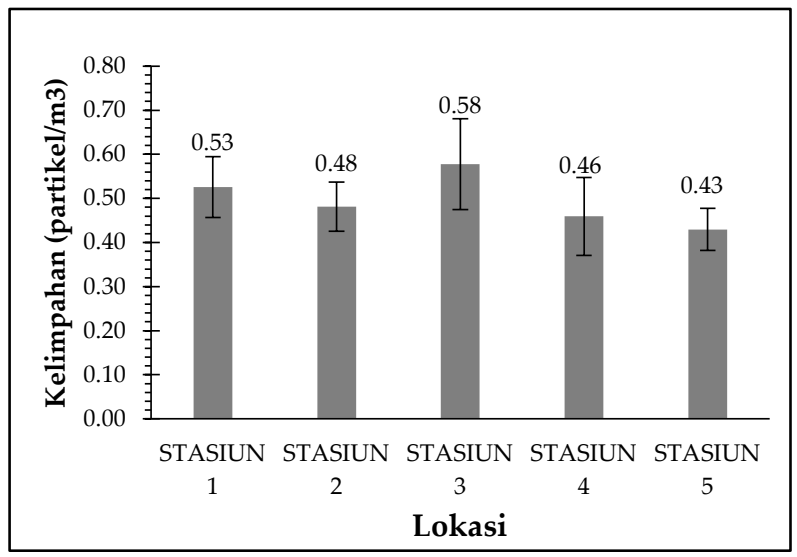

Gambar 4. Kelimpahan Total Mikroplastik di Perairan Teluk Benoa

Rata-rata jumlah partikel mikroplastik yang ditemukan pada Stasiun 1 sebanyak 23,3 partikel Tabel 1

Perbandingan Kelimpahan Mikroplastik (Air) di Lokasi Pengambilan Sampel dengan Kawasan Pesisir lainnya

\begin{tabular}{|c|c|c|c|}
\hline No & Lokasi & $\begin{array}{l}\text { Kelimpahan } \\
\left(\text { Partikel } / \mathrm{m}^{3}\right)\end{array}$ & Referensi \\
\hline & & Rata-rata & \\
\hline 1 & $\begin{array}{l}\text { Daerah dekat Muara Sungai Badung } \\
\text { dan Sungai Mati }\end{array}$ & 0,53 & Penelitian ini \\
\hline 2 & Daerah dekat TPA Suwung & 0,48 & Penelitian ini \\
\hline 3 & $\begin{array}{l}\text { Daerah dekat Pelabuhan Benoa bagian } \\
\text { Selatan }\end{array}$ & 0,58 & Penelitian ini \\
\hline 4 & Daerah muara Sungai Sama & 0,46 & Penelitian ini \\
\hline 5 & Daerah dekat muara Sungai Bualu & 0,43 & Penelitian ini \\
\hline 6 & Perairan Timur laut Amerika Serikat & $0,01-0,26$ & Carpenter et al., 1972 \\
\hline 7 & Pusaran Pasifik Utara & 2,23 & Moore et al., 2001 \\
\hline 8 & Pesisir Selatan California & 7,25 & Moore et al., 2002 \\
\hline 9 & $\begin{array}{l}\text { Teluk Santa Monica - Selatan } \\
\text { California }\end{array}$ & 3,92 & Lattin et al., 2004 \\
\hline 10 & Atlantik & 0,020 & Law et al., 2010 \\
\hline 11 & Kepulauan Karibia & 0,001 & Law et al., 2010 \\
\hline 12 & Teluk Maine - Amerika Utara & 0,001 & Law et al., 2010 \\
\hline 13 & Perairan Barat laut Mediterania & 0,116 & Collignon et al., 2012 \\
\hline 14 & Timur laut Samudera Pasifik & $0,004-0,19$ & Doyle et al., 2011) \\
\hline 15 & Kepulauan Stockholm & $0,19-7,73$ & Gewert et al., 2017 \\
\hline
\end{tabular}

dengan kelimpahan yaitu 0,52 partikel $/ \mathrm{m}^{3}$. Stasiun 1 berlokasi di dekat mulut muara dari Sungai Badung dan Sungai Mati. Masukan sampah plastik pada stasiun 1 diduga dibawa oleh arus dari sungai tersebut. Keberadaan sampah plastik yang di kedua sungai tersebut diduga bersumber dari sampah rumah tangga yang dibuang secara sengaja maupun tidak sengaja ke sungai. Sungai Mati dan Sungai Badung merupakan sungai yang melewati kawasan perkotaan di Kota Denpasar dan Kabupaten Badung. Menurut Jambeck et al. (2015), bahwa input utama dari sampah plastik diketahui berasal dari daerah-daerah padat penduduk atau industri.

Rata-rata jumlah partikel mikroplastik yang ditemukan pada Stasiun 2 sebanyak 21,7 partikel dengan kelimpahan 0,48 partikel $/ \mathrm{m}^{3}$. Lokasi stasiun 2 yaitu di dekat TPA Suwung dan dekat dengan Pulau serangan bagian Barat. Masukan sampah plastik ke stasiun 2 ini diduga masih dipengaruhi oleh aktivitas pelabuhan Benoa dan dermaga kapal di bagian barat Pulau Serangan. Sampah plastik yang diduga berasal dari aktivitas tersebut terbawa arus hingga sampai ke stasiun 2 .

Rata-rata jumlah partikel mikroplastik yang ditemukan pada Stasiun 3 sebanyak 26,0 partikel dengan kelimpahan 0,58 partikel $/ \mathrm{m}^{3}$. Stasiun 3 adalah lokasi dengan temuan tertinggi 


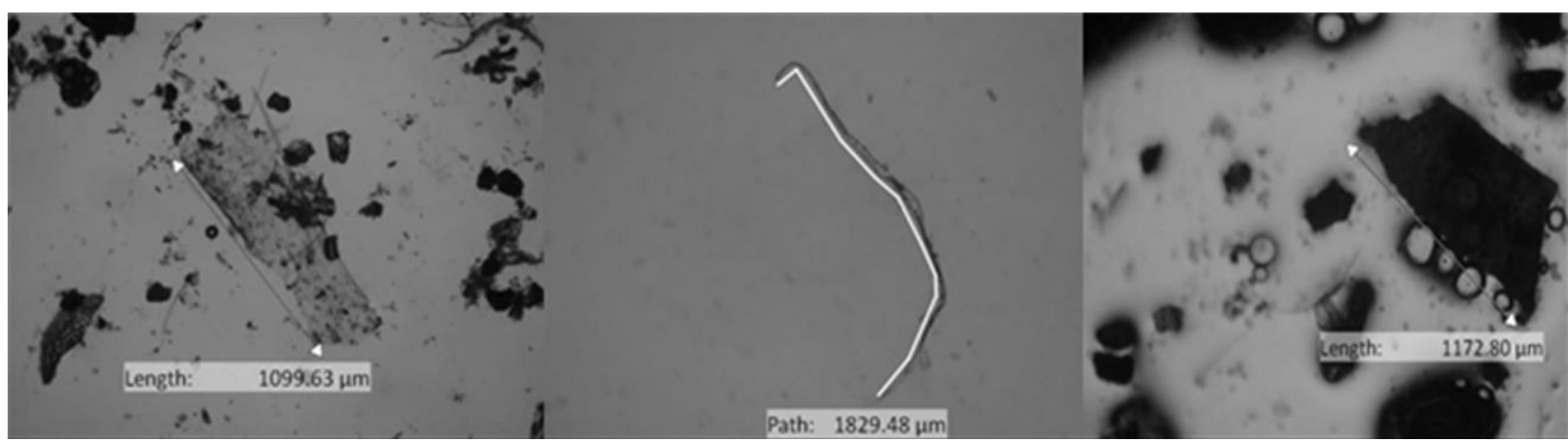

Gambar 5. Jenis Mikroplastik yang ditemukan di sedimen Perairan Teluk Benoa Fragmen (a), Film (b), dan Fiber (c)

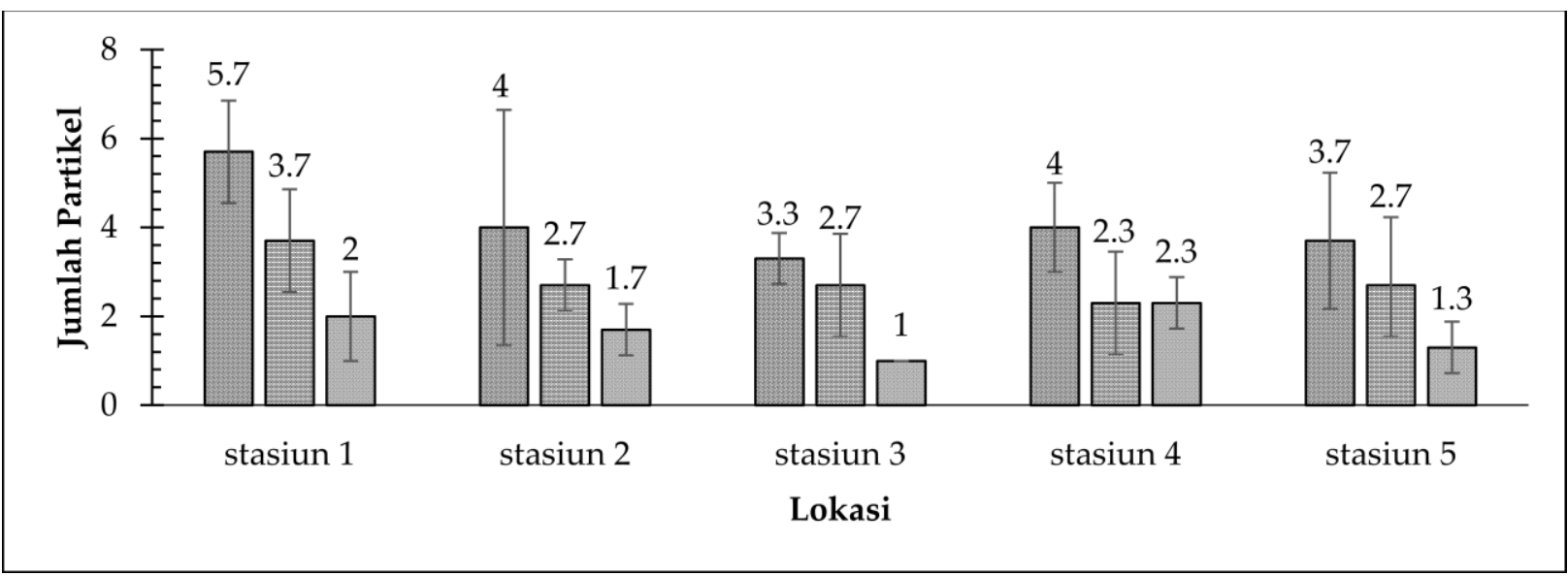

Gambar 6. Distribusi jumlah mikroplastik jenis fragmen (隥), film (園), dan fiber (不) pada 5 stasiun amatan di Sedimen Teluk Benoa.

mikroplastik dibandingkan dengan stasiun lainnya. Stasiun 3 berlokasi dekat dengan pelabuhan Benoa dan dekat dengan mulut teluk (antara Pulau Serangan dan Tanjung Benoa). Banyaknya jumlah mikroplastik yang ditemukan di stasiun 3 diduga karena pengaruh dari aktivitas yang terjadi di pelabuhan. Secara visual saat dilakukan pengambilan data, dapat terlihat sampah-sampah plastik terdiri dari kantong plastik, kemasan makanan, perlengkapan mandi. Pembuangan sampah plastik secara langsung ke laut diduga masih terjadi dari kapal-kapal yang beraktivitas di sekitar Pelabuhan Benoa yang mengakibatkan adanya sampah plastik di stasiun ini. Hal ini sesuai dengan pernyataan UNEP (2005), bahwa kapal adalah salah satu sumber sampah selain platform minyak dan gas lepas pantai, serta instalasi akuakultur. Selain faktor tersebut, sampah plastik yang ada di stasiun 3 diduga bersumber dari muara Sungai Badung dan Sungai Mati yang terbawa arus ke lokasi ini.

Rata-rata jumlah partikel mikroplastik yang ditemukan pada Stasiun 4 sebanyak 20,7 partikel dengan kelimpahan $0,46 \mathrm{partikel} / \mathrm{m}^{3}$. Stasiun 4 berlokasi di dekat muara Sungai Sama. Sumber masukan sampah plastik pada stasiun 4 ini yaitu diduga berasal dari Kawasan pemukiman yang dilewati oleh aliran Sungai Sama dan pemukiman yang berada dekat dengan stasiun 4. Selain itu, masukkan sampah di stasiun 4 juga diduga bersumber dari Sungai Bualu.

Rata-rata jumlah partikel mikroplastik yang ditemukan pada Stasiun 5 sebanyak 19,3 partikel dengan kelimpahan 0,43 partikel $/ \mathrm{m}^{3}$. Stasiun 5 adalah lokasi dengan temuan mikroplastik terendah dibanding stasiun lainnya, Stasiun 5 berlokasi di dekat muara Sungai Bualu. Sumber masukan sampah plastik di stasiun 5 diduga berasal dari Sungai Bualu dan Sungai Sama.

Dalam penelitian ini, kelimpahan mikroplastik yang ditemukan di perairan Teluk Benoa berkisar antara $0,43-0,58$ partikel $/ \mathrm{m}^{3}$. Kelimpahan tertinggi ditemukan di stasiun dekat Pelabuhan Benoa bagian selatan. Aktivitas pelabuhan diduga memiliki kontribusi terhadap tingginya kelimpahan mikroplastik di stasiun ini. Hal berbeda ditemukan oleh Gewert et al., (2017) di Kepulauan Stockholm bahwa kelimpahan mikroplastik yang ditemukan di dekat kota Stockholm $\left(7,73\right.$ partikel $\left./ \mathrm{m}^{3}\right)$ lebih tinggi dengan 
mikroplastik yang ditemukan di area pelabuhan Nynäshamn $\left(1,34\right.$ partikel $\left./ \mathrm{m}^{3}\right)$. Hal ini menunjukan bahwa selain aktivitas pelabuhan, sumber sampah dari daratan juga memiliki kontribusi terhadap sampah yang ada dilaut. Kelimpahan mikroplastik yang ditemukan di perairan Teluk Benoa masih tergolong lebih rendah jika dibandingkan dengan beberpa temuan peneliti seperti Moore et al., (2001) di Pusaran Pasifik Utara (2,23 partikel $\left./ \mathrm{m}^{3}\right)$, Moore et al., (2002) di Pesisir Selatan California (7,25 partikel $\left./ \mathrm{m}^{3}\right)$.

Jenis mikroplastik yang paling banyak ditemukan di perairan Teluk Benoa adalah fragmen. Empat dari lima stasiun pengambilan sampel jenis mikroplastik yang paling banyak yang ditemukan yaitu jenis fragmen. Hal ini sesuai dengan pernyataan Kovac (2016), bahwa fragmen merupakan jenis mikroplastik paling melimpah dibanding jenis lain. Jenis mikroplastik tertinggi kedua yang paling banyak ditemukan yaitu jenis film. Film memiliki densitas lebih rendah dibandingkan tipe mikroplastik lainnya sehingga lebih mudah ditransportasikan (Hastuti, 2014). Tingkatan frgamentasi plastik tergantung pada densitas plastik dan strukur bahan kimia pada plastik tersebut (Teuteun et al, 2009). Jenis mikroplastik terendah yang ditemukan yaitu jenis fiber. Menurut GESAMP (2015) fiber memiliki bentuk dan ukuran yang tipis menyebabkan fiber sering ditemukan mengapung di permukaan air. Pada stasiun 1 dan 3, secara visual terlihat sampah plastik yang mengapung. Penelitian Alomar et al. (2016) di Laut Mediterania juga menunjukkan adanya makroplastik yang terlihat mengapung di permukaan laut. Diduga persebaran makroplastik tersebut dipengaruhi oleh arus dan angin. Hal ini didukung oleh pernyataan Oliveira et al. (2015) arus dan angin yang kuat dapat mengangkut sampah jauh dari sumbernya. Kemudian makroplastik akan terpecah menjadi partikel yang lebih kecil karena cahaya, panas, kimia atau proses fisik (Andrady, 2011; Barnes et al., 2009).

\subsection{Mikroplastik di Sedimen Teluk Benoa}

Hasil penelitian menunjukkan bahwa di dalam sedimen yang diambil di perairan Teluk Benoa mengandung partikel mikroplastik. Jenis mikroplastik yang ditemukan yaitu fragmen, film, dan fiber. Partikel mikroplastik yang ditemukan di sedimen Teluk Benoa memiliki ukuran $90 \mu \mathrm{m}-2$ $\mathrm{mm}$.
Berdasarkan hasil penelitian, rata-rata mikroplastik jenis fragmen yang ditemukan berkisar antara 3,3 - 5,7 partikel. Jenis fragmen tertinggi ditemukan pada stasiun 1 dengan jumlah 5,7 partikel dan terendah ditemukan pada stasiun 3 dengan jumlah 3,3 partikel. Rata-rata mikroplastik jenis film yang ditemukan berkisar antara 2,3 - 3,7 partikel. Jenis film tertinggi ditemukan pada stasiun 1 dengan jumlah 3,7 partikel dan terendah ditemukan pada stasiun 4 dengan jumlah 2,3 partikel. Rata-rata mikroplastik jenis fiber yang ditemukan berkisar antara $1-2$ partikel. Jenis fiber tertinggi ditemukan pada stasiun 1 dengan jumlah 2 partikel dan terendah ditemukan pada stasiun 3 dengan jumlah 1 partikel. Jumlah dan jenis mikroplastik pada masing-masing stasiun secara rinci dapat dilihat pada Gambar 6.

Kelimpahan total mikroplastik di sedimen Teluk Benoa berkisar dari 70 - 114 partikel $/ \mathrm{kg}$. Kelimpahan tertinggi ditemukan pada stasiun 1 yaitu 113 partikel/ kg, sedangkan kelimpahan terendah ditemukan pada stasiun 3 yaitu 70 partikel/ kg. Kelimpahan total mikroplastik di masing-masing stasiun secara rinci dapat dilihat pada Gambar 7.

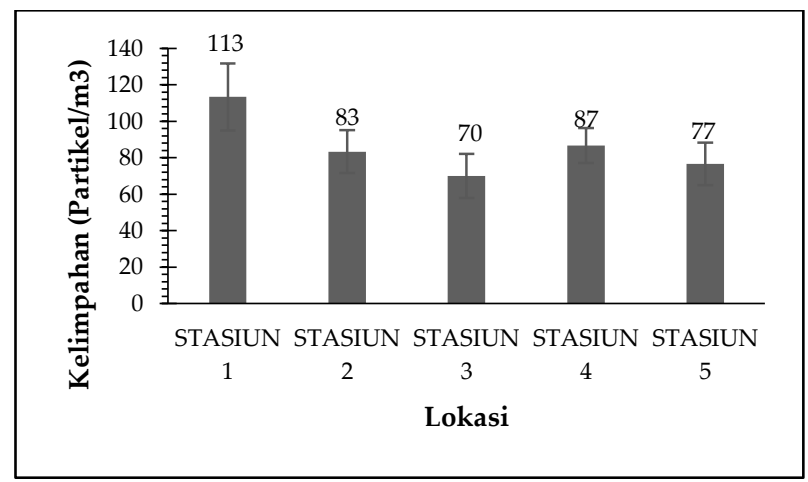

Gambar 7. Kelimpahan Total Mikroplastik di Sedimen Perairan Teluk Benoa

Jenis mikroplastik yang ditemukan di sedimen Teluk Benoa yaitu jenis fragmen, film, dan fiber. Penelitian Dewi (2015) di Muara Badak Kabupaten Kutai Kartanegara juga menemukan mikroplastik jenis fragmen, film, dan fiber. Jumlah mikroplastik yang ditemukan di sedimen Teluk Benoa yaitu 43 partikel dari 5 stasiun pengambilan sampel. Berdasarkan pengamatan secara visual tekstur sedimen di Teluk Benoa didominasi oleh sedimen berpasir dan lumpur. Tekstur sedimen tersebut mampu merangkap mikroplastik di perairan ketika surut. Hal ini sesuai dengan pernyataan Watters et al. (2010), bahwa sedimen lunak lebih dapat merangkap debris dibandingkan habitat 
Tabel 2

Perbandingan Kelimpahan Mikroplastik (Sedimen) di Lokasi Pengambilan Sampel Dengan Kawasan Pesisir lainnya

\begin{tabular}{|c|c|c|c|}
\hline No & Lokasi & $\begin{array}{c}\text { Kelimpahan } \\
\text { (partikel/kg } \\
\text { sedimen kering) }\end{array}$ & Pustaka \\
\hline \multicolumn{4}{|c|}{ Rata-rata } \\
\hline 1 & $\begin{array}{l}\text { Daerah dekat Muara Sungai Badung } \\
\text { dan Sungai Mati }\end{array}$ & 113 & Penelitian ini \\
\hline 2 & Daerah dekat TPA Suwung & 83 & Penelitian ini \\
\hline 3 & $\begin{array}{l}\text { Daerah dekat Pelabuhan Benoa } \\
\text { bagian Selatan }\end{array}$ & 73 & Penelitian ini \\
\hline 4 & Daerah dekat muara Sungai Sama & 87 & Penelitian ini \\
\hline 5 & Daerah dekat muara Sungai Bualu & 77 & Penelitian ini \\
\hline 6 & Pulau Mallorca dan Pulau Cabrera & $100,78-897,35$ & Alomar et al., 2016 \\
\hline 7 & Pesisir Belgian & $93-167$ & Claessens et al., 2011 \\
\hline 8 & Lamun, Pulau Semelue & 5,8 & Cordova dan Hernawan, 2017 \\
\hline 9 & $\begin{array}{l}\text { Daerah Muara, Pesisir Desa Jaring } \\
\text { Halus Kab. Langkat }\end{array}$ & 64 & Persedantabangun, 2017 \\
\hline 10 & $\begin{array}{l}\text { Daerah dekat pemukiman penduduk, } \\
\text { Pesisir Desa Jaring Halus Kab. } \\
\text { Langkat }\end{array}$ & 173,33 & Persedantabangun, 2017 \\
\hline 11 & $\begin{array}{l}\text { Daerah nihil kegiatan masyarakat, } \\
\text { Pesisir Desa Jaring Halus Kab. } \\
\text { Langkat }\end{array}$ & 89 & Persedantabangun, 2017 \\
\hline 12 & $\begin{array}{l}\text { Batas terluar mangrove, Pantai Indah } \\
\text { Kapuk Jakarta }\end{array}$ & $216,8-2218,4$ & Hastuti, 2014 \\
\hline 13 & $\begin{array}{l}\text { Batas terdalam mangrove, Pantai } \\
\text { Indah Kapuk Jakarta }\end{array}$ & $191,4-2357,6$ & Hastuti, 2014 \\
\hline
\end{tabular}

berbatu dan kerikil. Ukuran butir sedimen dapat mempengaruhi deposisi mikroplastik dalam sedimen (Chakraborty et al., 2015), namun konsentrasi mikroplastik tidak meningkat dengan penurunan ukuran butir sedimen seperti halnya untuk bahan organik dan kontaminan lainnya (Bergamaschi et al. , 1997; Chakraborty et al., 2015). Browne et al. (2010) tidak mengamati adanya hubungan yang jelas antara kelimpahan mikroplastik $(<1 \mathrm{~mm})$ dan proporsi lempung dalam sedimen yang dianalisis dan berpendapat bahwa proses lain seperti agregasi dengan bahan organik mungkin memainkan peran yang lebih penting dalam pergerakan mikroplastik (Van Cauwenberghe et al., 2015).

Jenis mikroplastik yang paling banyak ditemukan pada setiap stasiun yaitu mikroplastik jenis fragmen. Hal ini dibuktikan karena fragmen merupakan hasil potongan produk plastik dengan polimer sintesis yang sangat kuat (Kingfisher, 2011 dalam Hastuti, 2014). Umumnya pada sampel sedimen jenis polimer yang dapat ditemukan yaitu
PVC, nilon, dan PET yang akan lebih cenderung tenggelam (Avio et al., 2016; Carr et al., 2016). Hal ini dijelaskan pula bahwa mikroplastik dengan densitas yang lebih besar dari air laut akan tenggelam dan akan terakumulasi didalam sedimen, sedangkan mikroplastik dengan densitas yang lebih kecil dari air laut akan bersifat lebih ringan dan berada dipermukaan laut (Woodall et al., 2014; Alomar et al., 2016; Suaria and Aliani, 2014).

Mikroplastik jenis film merupakan salah satu jenis mikroplastik yang yang ditemukan dengan kelimpahan tertinggi kedua setelah jenis fragmen. Penelitian Dewi (2015), juga menemukan bahwa film ditemukan memiliki kelimpahan rata-rata tertinggi kedua setelah fragmen dengan nilai 86,88 partikel/kg. Hal ini membuktikan bahwa mikroplastik tipe film yberasal dari fragmentasi kantong plastik atau plastik kemasan merupakan limbah padat yang berada di kawasan Teluk Benoa. sedimen perairan Teluk Benoa yaitu jenis Fiber. Mikroplastik jenis fiber yang berada di sedimen 
perairan Teluk Benoa diduga berasal dari sisa-sisa potongan alat tangkap yang digunakan nelayan yang melakukan aktifitas di Teluk Benoa. Hal ini merujuk dari pendapat bahwa fiber merupakan material yag berasal dari alat pancing dan pakaian (UNEP, 2016). Selain itu fiber juga berasal dari pakaian sintetis. Menurut Browne et al. (2011), jenis mikroplastik ini menunjukkan asal limbah dari pakaian sintetis industri tekstil, bahkan 1900 fiber dapat dilepaskan ke lingkungan dari mencuci satu potong pakaian.

Benoa berkisar 77 - 113 partikel/kg sedimen kering. Kelimpahan tertinggi ditemukan di daerah dekat muara Sungai Badung dan Sungai Mati. Hal berbeda ditemukan oleh Persedantabangun (2017) di Pesisir Desa Jaring Halus Kab. Langkat bahwa pada stasiun yang berlokasi daerah muara Desa Jaring Halus merupakan stasiun yang memiliki nilai kelimpahan mikroplastik terendah (64 partikel $/ \mathrm{kg}$ sedimen kering) dibanding dengan stasiun lainnya. Penelitian Hastuti (2014) di batas terluar mangrove Pantai Indah Kapuk Jakarta ditemukan kelimpahan 216,8 - 2218,4 partikel/kg sedimen kering. 4 dari 5 stasiun dalam penelitian ini terletak di dekat kawasan mangrove yang ada di perairan Teluk Benoa. Hal ini menunjukkan bahwa kandungan mikroplastik di sedimen Teluk Benoa tergolong rendah jika dibandingkan dengan kandungan mikroplastik di kawasan mangrove Pantai Indah Kapuk Jakarta.

Mikroplastik yang memiliki densitas rendah akan cenderung mengapung, namun melalui modifikasi densitas, plastik dengan densitas rendah dapat tenggelam ke dasar perairan (Van Cauwenberghe et al., 2015). Modifikasi densitas dapat terjadi akibat dari biofouling yang dilakukan oleh prokariota, eukariota dan invertebrata dapat menyebabkan peningkatan kepadatan yang mengakibatkan tenggelamnya mikroplastik (Jorissen, 2014). Biofouling adalah akumulasi secara bertahap organisme dalam air seperti alga, bakteri, kerang, dan protozoa pada sebuah permukaan struktur peralatan bawah air, struktur pipa, struktur lambung kapal dan lain-lain yang dapat menimbulkan sifat korosi dari struktur yang ditumbuhinya, sehingga dapat membuat gangguan dari struktur dan sistem peralatan.

\section{Simpulan}

Jenis mikroplastik yang didapatkan di air dan sedimen perairan Teluk Benoa yaitu fragmen, film, dan fiber. Kelimpahan mikroplastik di perairan Teluk Benoa pada setiap stasiun ( stasiun 1-5 ) masing-masing yaitu 0,53 partikel $/ \mathrm{m}^{3}, \quad 0,48$ partikel $/ \mathrm{m}^{3}, 0,58$ partikel $/ \mathrm{m}^{3}, 0,46 \mathrm{partikel} / \mathrm{m}^{3}$, dan $0,43 \mathrm{partikel} / \mathrm{m}^{3}$. Nilai ini tergolong rendah jika dibandingkan dengan temuan peneliti lain di Pusaran Pasifik Utara dan di Pesisir Selatan California. Kelimpahan mikroplastik di sedimen perairan Teluk Benoa pada setiap stasiun ( stasiun 1-5 ) yaitu 113 partikel/kg sedimen kering, 83 partikel/kg sedimen kering, 73 partikel/kg sedimen kering, 87 partikel $/ \mathrm{kg}$ sedimen kering, dan 77 partikel/kg sedimen kering. Nilai ini tergolong rendah jika dibandingkan dengan temuan peneliti lain di batas terluar mangrove Pantai Indah Kapuk Jakarta.

\section{Ucapan terimakasih}

Penulis mengucapkan terima kasih kepada Tuhan Yang Maha Esa, Kedua Orangtua penulis, Fakultas Kelautan dan Perikanan, Ibu/Bapak Dosen dan teman-teman Manajemen Sumberdaya Perairan angkatan 2014 khususnya Suci, Agung Dwikhy, Bella, Muttaqin, Gagah, Sulthon, Adiguna dan Koming yang telah membantu dalam pengambilan data serta Kemristekdikti yang telah memberikan beasiswa bidikmisi kepada penulis.

\section{Daftar Pustaka}

Alomar, C., Estarellas, F., \& Deudero, S. (2016). Microplastics in the Mediterranean Sea: deposition in coastal shallow sediments, spatial variation and preferential grain size. Mar. Environ. Res., 115, 1-10.

Andrady, A. L., (2011). Microplastics in the marine environment. Marine Pollution Bulletin, 62, 1596-1605.

Aruna. 2017. Sampah Laut, Ancaman Nyata Ekosistem Laut. $\quad$ https://aruna.id/2017/05/12/sampah-lautancaman-nyata-ekosistem-laut/. [20 November 2017].

Avio, C. G., Gorbi, S., Milan, M., Benedetti, M., Fattorini, D., d'Errico, G., Pauletto, M., Bargelloni, L., \& Regoli, F., (2016). Pollutants bioavailability and toxicological risk from microplastics to mussels. Environ. Pollut. 198, 211- 222.

Barnes, D. K. A., Galgani, F., Thompson, R. C., \&Barlaz, M. (2009). Accumulation and fragmentation of plastic debris in global environments. Philos. Trans. R. Soc. $B$ Biol. Sci., 364, 1985-1998.

Bergamaschi, B. A., Tsamakis, E., Keil, R. G., Eglinton, T. I., Montluçon, D. B., \& Hedges, J. I. (1997). The effect of grain size and surface area on organic matter, lignin and carbohydrate concentration, and molecular compositions in Peru margin sediments. Geochim. Cosmochim. Acta 61, 1247-1260. 
Boerger, C. M., G. L. Lattin, S. L. Moore, \& C. J. Moore. (2010). Plastic ingestion by planktivorous fishes in the North Pacific Central Gyre. Mar. Poll. Bull., 60, 22752278.

Browne, M. A., Dissanayake, A., Galloway, T. S., Lowe, D. M., \& Thompson, R. C. (2008). Ingested microscopic plastic translocates to the circulatory system of the mussel, Mytilus edulis (L.). Environ. Sci. Technol. 42, 5026e5031.

Browne, M.A., Galloway, T.S., \& Thompson, R.C.,( 2010). Spatial patterns of plastic debris along estuarine shorelines. Environ. Sci. Technol, 44, 3404-3409.

Carpenter, E. ., Miklas, H. P. ,Peck, B. B., Anderson, S. J., \& Harvey, G. R. 1972. Polystyrene spherules in coastal waters. Science (Wash.), 178, 749-750.

Carr, S. A., Liu, J., \& Tesoro, A. G. (2016). Transport and fate of microplastic particles in wastewater treatment plants. Water Res. 91(2016), 174- 182.

Chakraborty, P., Sarkar, A., Vudamala, K., Naik, R., \& Nath, B. N., (2015). Organic Matter - A Key Factor in Controlling Mercury Distribution in Estuarine Sediment. Marine Chemistry, 173, 302-309.

Citrasari, N., N.I. Oktavitri, A. Nuril, \& Aniwindira. (2012). Analisis laju timbunan dan komposisi sampah di permukiman pesisir Kenjeran Surabaya. J. Biol. Res., 18, 83-85.

Collignon, A., Hecq, J., Glagani, F., Voisin, P., Collard, F., \& Goffart, A. (2012). Neustonic microplastic and zooplankton in the North Western Mediterranean Sea. Mar. Poll. Bull., 64(2012), 861-864.

Convention on Biological Diversity; Scientific and Technical Advisory Panel. (2012). Impacts of Marine Debris on Biodiversity: Current Status and Potential Solutions. CBD Technical Series No. 67. Montreal (CA): Secretariat of the Convention on Biological Diversity. p 23.

Cordova, M. R., \& Hernawan, U. E., (2017). Distribusi Mikroplastik Kawasan Padang Lamun Pulau Simeuleu. Ekspedisi Widya Nusantara 2017: Simeulue \& NorthWestern Sumatra Water. Jakarta, Indonesia: Pusat Penelitian Oseanografi Lembaga Ilmu Pengetahuan Indonesia.

Dewi, I. S., Budiarsa, Anugrah, A., Ritonga, \& Irwan, R. (2015). Distribusi mikroplastik pada sedimen di Muara Badak, Kabupaten Kutai Kartanegara . Depik, 4(3): 121-131

Doyle, M. J., Watson, W., Bowlin, N.M., \& Sheavly, S.B., (2011). Plastic particles in coastal pelagic ecosystems of the Northeast Pacific ocean. Mar. Environ. Res., 71, 41-52.

Galgani, F. (2015). The Mediterranean Sea: From litter to microplastics. Micro 2015: Book of abstracts.

GESAMP (Joint Group of Experts on the Scientific Aspects of Marine Environmental Protection). 2015. Sources, Fate and Effects of Microplastics in The Marine Environment: A Global Assessment (Kershaw, P. J., ed.). (IMO/FAO/UNESCOIOC/UNIDO/WMO/IAEA/UN/U
NEP/UNDP Joint Group of Experts on The Scientific Aspects of Marine Environmental Protection). Rep. Stud. GESAMP No. 90, 96p

Gewert, B., Ogonowski, M., Barth, A., \& MacLeod, M.. (2017). Abundance and composition of near surface microplastics and plastic debris in the Stockholm Archipelago, Baltic Sea. Mar. Poll. Bull., 120 (2017) 292 -302 .

Hastuti A. R. (2014). Distribusi Spasial Sampah Laut Di Ekosistem Mangrove Pantai Indah Kapuk Jakarta. Skripsi. Bogor, Indonesia: Departemen Manajemen Sumber Daya Perairan, Institut Pertanian Bogor.

Hidalgo-Ruz, V., Gutow, L., Thompson, R.C., \& Thiel, M. (2012). Microplastics in the marine environment: a review of the methods used for identification and quantification. Environmental Science and Technology, 46,30603075.

Jambeck, J. R, Geyer, R., Wilcox, C., Siegler, T.R., Perryman, M. (2015). Plastic waste inputs from land into the ocean. Science, 347,768-71.

Jorissen, F. J., (2014). Colonization by the benthic foraminifer Rosalina (Tretomphalus) concinna of Mediterranean drifting plastics in CIESM 2014. In: Briand, F. (Ed.), Marine litter in the Mediterranean and Black Seas. CIESM Publisher, Monaco, p. 180.

Kovac Virsek, M., Palatinus, A., Koren, S., Peterlin, M., Horvat, P., \& Krzan, A. (2016). Protocol for Microplastics Sampling on the Sea Surface and Sample Analysis. J. Vis. Exp. 118, e55161.

Lattin, G. L., Moore, C. J., Zellers, A. F., Moore, S. L., Weisberg, S. B., (2004). A comparison of neustonic plastic and zooplankton at different depths near the southern California shore. Mar. Pollut. Bull., 49, 291294.

Law, K., Morét-Ferguson, S., Maximenko, N., Proskurowski, G., Peacock, E., Hafner, J., Reddy, C., (2010). Plastic accumulation in the North Atlantic Subtropical Gyre. Science, 329, 1185-1188.

Lusher A. L., McHugh M, \& Thomson R.C,. (2012). Occurrence of microplastic in the gastrointestal tract of pelagic and demersal fish from the English Channel. Mar. Pollut. Bull., 67, 94-99.

Marhaeni, Bintang. (2012). Biofouling Pada Beberapa Jenis Substrat Permukaan Kasar dan Halus. Sains Akuatik, 14(1), 41 - 47

Moore, C. J., Moore, S. L., Weisberg, S. B., Lattin, G. L., Zellers, A. F., (2002). A comparison of neustonicplastic andzooplankton abundancein southernCalifornia's coastal waters. Mar. Pollut. Bull., 44, 1035-1038.

Moore,C. J., Moore, S.L., Leecaster, M. K., Weisberg, S. B., (2001). Acomparison of plastic and plankton in the North Pacific Central Gyre. Mar. Pollut. Bull., 42 (12), 1297- 1300.

National Oceanic and Atmospheric Administration. (2013). Programmatic environmental assessment (PEA) for the NOAA Marine Debris Program (MDP). Maryland (US): NOAA. 168 p. 
Persedantabangun, A., (2017). Jenis dan Kepadatan Sampah Laut (Makro dan Mikro Plastik) Serta Dampaknya Terhadap Kepadatan Makrozoobenthos Di Pesisir Desa Jaring Halus Kabupaten Langkat Sumatera Utara. Skripsi. Medan, Indonesia: Fakultas Pertanian, Universitas Sumatera Utara.

Suaria, G., \&Aliani, S., 2014. Floating debris in the Mediterranean sea. Mar. Pollut. Bull., 86, 494-504.

Teuten, E. L, Saquing, J. M., Knappe, D. R. U., Barlaz, M. A., Jonsson, S., Bjorn, A., Rowland, S. J, Thompson, R.C., Galloway, T.S., \& Yamashita, R. (2009). Transport and release of chemicals from plastics to the environment and to wildlife. Philosophical Transactions of the Royal Society B. 364, 20272045

United Nations Environment Programme. 2005. Marine Litter, an Analytical Overview.

United Nations Environment Programme. 2011. Emerging issues in our global environment. Nairobi (KE): UNEP. 79 p.

United Nations Environment Programme. 2016. UNEP Frontiers 2016 Reports: Emerging issues of environmental Concern. UNEP, Nairobi
Van Cauwenberghe, L., Claessens, M., Vandegehuchte, M., \& Janssen, C.R., (2015). Microplastics are taken up by mussels (Mytilus edulis) and lugworms (Arenicola marina) living in natural habitats. Environ. Pollut. 199, 10-17.

Van Cauwenberghe, L.M., Claessens, M.B., Vandegehuchte, J., Mees, C.R., Janssen. (2013). Assessment of marine debris on the Belgian Continental Shelf. Mar. Poll. Bull., 73, 161-169.

Victoria, A.V. (2017). Kontaminasi Mikroplastik di Perairan Tawar. Skripsi. Bandung, Indonesia, Teknik Kimia, Institut Teknologi Bandung.

Wardhana, W. (2003). Teknik Sampling, Pengawetan dan Analisis Plankton. Jakarta, Indonesia: Departemen Biologi Fakultas Matematika Ilmu Pengetahuan Alam, Universitas Indonesia.

Watters, D.L., M.M. Yoklavich, M.S. Love, \& D.M. Schroeder. (2010). Assessing marine debris in deep seafloor habitats off California. Marine Pollution Bulletin, 60,131-138.

Woodall, L. C. (2014). The deep sea is amajor sink formicroplastic debris. R. Soc. Open Sci. 1, 140317. 